Pengembangan Rekayasa dan Teknologi, Vol 13, No. 2, Desember 2017, pp 58-64

p-ISSN: 1410-9840 \& e-ISSN: 2580-8850

http://journals.usm.ac.id/index.php/jprt/index

\title{
Pengaruh Waktu Ekstraksi dan Konsentrasi Ekstrak Rambut Jagung (Corn Silk) Terhadap pH, Total Fenol Dan Aktivitas Antibakteri
}

\author{
Haslina dan Sri Untari \\ ${ }^{1}$ Faculty of Agriculture Technology, Semarang University, Jl.Soekarno Hatta, Semarang 50196, \\ Central Java, Indonesia \\ Email:chana_panca@yahoo.com
}

\begin{abstract}
The growth of microorganisms in foodstuffs can lead to profitable changes such as nutritional improvements in food, digestibility or storage. In addition, the growth of microorganisms in food can also lead to undesirable physical and chemical changes, so the food is not worth consuming. Staphylococcus aureus and Escherichia coli are the bacteria that often cause infection in humans. To prevent this it is necessary to have bioactive components that can inhibit the growth of microorganisms. Active compounds such as saponins, triterpenoids, phenols, tannins, flavonoids and alkaloids are known to have antibacterial activity. Several studies have reported the chemical content found in corn hair. Corn hair is part of a corn plant that has not been used effectively because it is considered as waste. Based on research, corn hair contains proteins, vitamins, carbohydrates, calcium salts, potassium, magnesium, and sodium, essential oils, steroids such as sitosterol and stigmasterol, alkaloids, saponins, tannins, and flavonoids. So presumably corn hair extract has antibacterial activity.

This study aims to determine the effect of extraction time and concentration of corn hair extract on $\mathrm{pH}$, total phenol and antibacterial activity.

The experimental design used in this study was Randomized Block Design (RBD) with 3 replications. The treatments used were Extraction Time A1 $=30$ minutes, $\mathrm{A} 2=40$ minutes, $\mathrm{A} 3=50$ minutes and Concentration Extract (material: solvent) $\mathrm{K} 1=75 \%(\mathrm{w} / \mathrm{v}), \mathrm{K} 2=50 \%(\mathrm{w} / \mathrm{v}), \mathrm{K} 3=25 \%(\mathrm{w} / \mathrm{v})$. Furthermore, the data obtained were analyzed variant and if there was any difference between treatments followed by Duncan Multiple Range Test (DMRT) test at 5\% level. The results showed that all treatments produced bioactive compounds and formed inhibit zone of each test bacteria. The best time to obtain an antibacterial antibacterial extract on corn hair is 50 minutes. This was supported by the lowest $\mathrm{pH}$ average of 5.1 and the highest mean total phenol obtained from treatment $\mathrm{A} 3$ (50 minutes) was $7288,64 \mu \mathrm{gGAE} / \mathrm{g}$ and at $75 \%$ concentration formed the largest bacterial inhibition zone in each test bacteria.
\end{abstract}

Keywords: Corn Silk, Extractive Time, Concentration of Extract, pH, Total Phenol, Antibacterial Activity

\section{PENDAhUluAN}

Bahan makanan selain sebagai sumber gizi bagi manusia, juga merupakan sumber makanan bagi mikroorganisme. Pertumbuhan mikroorganisme dalam bahan pangan dapat menyebabkan perubahan yang menguntungkan seperti perbaikan bahan pangan secara gizi, daya cerna ataupun daya simpannya. Selain itu, pertumbuhan mikroorganisme dalam bahan pangan juga dapat mengakibatkan perubahan fisik dan kimia yang tidak diinginkan, sehingga bahan pangan tersebut tidak layak dikonsumsi. Kejadian ini biasanya terjadi pada pembusukan bahan pangan. Bahan pangan dapat bertindak sebagai perantara atau substrat untuk pertumbuhan mikroorganisme patogenik dan organisme lain penyebab penyakit (Siagian, 2002). Staphylococcus aureus dan Escherichia coli adalah bakteri yang sering menyebabkan infeksi pada manusia (Brooks, 2007). Untuk mencegah hal tersebut maka perlu adanya komponen bioaktif yang mampu menghambat pertumbuhan mikroorganisme. Senyawa aktif seperti saponin, triterpenoid, fenol, tanin, flavonoid dan alkaloid diketahui memiliki aktivitas antibakteri (Rosyidah, 2010).

Beberapa penelitian telah melaporkan kandungan kimia yang terdapat pada rambut jagung. Rambut jagung merupakan bagian dari tanaman jagung yang belum dimanfaatkan secara efektif karena dianggap sebagai limbah. Rambut jagung mengandung senyawa bioaktif yang bermanfaat bagi tubuh. Selain mengandung senyawa bioaktif, rambut jagung memiliki khasiat sebagai obat tradisional. Berdasarkan penelitian, rambut jagung mengandung protein, vitamin, karbohidrat, garam-garam kalsium, kalium, magnesium, dan natrium, minyak atsiri, steroid seperti sitosterol dan stigmasterol, alkaloid, saponin, tanin, dan flavonoid (Guo and Liu, 2009). Sehingga diduga ekstrak rambut jagung memiliki aktivitas antibakteri.

Ekstraksi merupakan langkah awal dalam memisahkan komponen bioaktif. Ekstraksi dengan pelarut sering digunakan untuk mengekstraksi senyawa bioaktif tanaman. Ekstraksi antioksidan tanaman tergantung pada kelarutan komponen antioksidan dari tanaman dalam pelarut (Spigno et.al., 2010). Penelitian tentang penggunaan pelarut yang berbeda polaritasnya untuk mengekstrak antioksidan telah banyak dilakukan. Hasil penelitian Selcuk, et.al., (2011) memilih metanol $70 \%(\mathrm{v} / \mathrm{v})$, dengan rasio 10:1 (v/w) sebagai pelarut paling efektif untuk ekstraksi polifenol biji anggur dibanding eseton dan air untuk semua konsentrasi bahan.

Menurut Ruenroengklin et.al., (2008) pengaruh berbagai suhu ekstraksi dari $30^{\circ} \mathrm{C}$ sampai 
$80^{\circ} \mathrm{C}$ terhadap hasil ekstraksi fenolik pada jaringan pericarp buah Kelengkeng, suhu ekstraksi $60^{\circ} \mathrm{C}$ adalah yang terbaik dalam hal hasil ekstraksi gabungan fenolik. Hal ini karena sifat kimia senyawa flavonoid yang dimiliki setiap tanaman bervariasi dari yang sederhana sampai senyawa flavonoid yang kompleks. Oleh karena itu, hasil ekstraksi selalu mengandung campuran senyawa dari golongan berbeda yang dapat larut dalam sistem pelarut yang dipilih (Oreopoulou, 2003; Marston and Hostettman, 2006). Berdasarkan penelitian Ibrahim (2014) nilai total fenol tertinggi terdapat pada perlakuan lama ekstraksi 25 menit, sedangkan nilai total fenol terendah terdapat pada lama waktu ekstraksi 15 menit. Berdasarkan penelitian Haslina dan Wahjuningsih (2013) pada serbuk effervescent yang dibuat dari ekstrak bunga Belimbing Wuluh didapat bahwa dengan perlakuan rasio (bunga:pelarut) 1:1 dan waktu ekstraksi selama 40 menit dengan pelarut etanol menghasilkan kadar antosianin, intensitas warna merah, dan fenol yang paling baik. Penelitian Haslina dan Wahjuningsih (2017) pada ekstrak rambut jagung menunjukkan bahwa pelarut metanol dan suhu $60^{\circ} \mathrm{C}$ menghasilkan total fenol, flavonoid, betakaroten dan aktivitas antioksidan terbaik.

Aktivitas antibakteri pada ekstrak juga dipengaruhi oleh konsentrasi ekstrak yang digunakan. Hasil penelitian Agustin (2016) menunjukkan bahwa ekstrak bunga Belimbing Wuluh dengan konsentrasi ekstrak $75 \%$ memiliki aktivitas antibakteri terbaik dengan membentuk zona hambat bakteri pada masingmasing bakteri uji yaitu $20 \mathrm{~mm}$ pada Escherichia coli dan $18 \mathrm{~mm}$ pada Staphylococcus aureus yang di uji dengan metode sumuran/difusi agar. Metode sumuran dipilih karena mudah dilakukan, tidak memerlukan peralatan khusus dan relatif murah. (Pelczar et al 1988 dalam Prayoga 2013). Pada penelitian ini ekstraksi dilakukan dengan pelarut metanol yang diharapkan dapat memisahkan komponen-komponen berdasarkan polaritasnya. Ekstraksi dengan metanol dapat melarutkan senyawa yang lebih polar. Ekstrak kemudian dianalisis profil $\mathrm{pH}$, total fenol dan aktivitas antibakteri dengan berbagai konsentrasi menggunakan metode sumuran/difusi agar.

\section{METODE PENELITIAN}

\section{a. Bahan}

Bahan baku pada penelitian ini adalah rambut jagung dari varietas lokal dengan umur 70 hari. Pelarut yang digunakan dalam penelitian ini yaitu metanol. Bakteri yang digunakan adalah Escherichia coli yang mewakili bakteri gram negatif dan Staphylococcus aureus yang mewakili bakteri gram positif.

\section{b. Alat}

Alat yang digunakan untuk proses ekstraksi adalah becker glass, blender, water bath, cawan petri, $\mathrm{pH}$ meter dan beberapa peralatan gelas untuk analisis. Alat yang digunakan untuk uji antibakteri adalah cawan petri, tabung reaksi, kertas, kapas, botol media, jarum ose, inkubator, pinset, autoklaf, bunsen, pipet mikro dan penggaris.

\section{c. Prosedur Penelitian}

Penelitian ini dilakukan dalam dua tahap, yaitu :

1. Penelitian Tahap I

a. Persiapan Sampel

Rambut jagung segar dicuci dengan air suling (aquadest) dikeringkan dengan oven pada suhu $60^{\circ} \mathrm{C}$ selama 24 jam (Hu et al., 2010) sampai kadar air akhir $10 \%$, ditumbuk menjadi bubuk menggunakan penggiling, vakum dikemas dan disimpan $<-20{ }^{\circ} \mathrm{C}$ sampai analisis.

b. Ekstraksi rambut jagung

3 gr bubuk rambut jagung dilarutkan dengan proporsi bahan dan pelarut adalah 1:4 (Burin et al., 2011) pada suhu ruang selama 24 jam dengan cara maserasi. Ekstraksi dilakukan pada suhu $70^{\circ} \mathrm{C}$ dengan water bath shaker 1,5 jam kemudian disaring pisahkan ampasnya. Pemisahan pelarut dengan rotary flash evaporator pada suhu $60^{\circ} \mathrm{C}$ (Hu et al., 2010 di dalam Li dan Yu, 2009). Larutkan residu dengan $5 \mathrm{ml}$ metanol, simpan suhu 0$4^{\circ} \mathrm{C}$.

\section{d. Rancangan Percobaan}

Rancangan percobaan yang digunakan dalam penelitian ini adalah Rancangan Acak Kelompok (RAK) dengan 3 kali ulangan. Perlakuan yang digunakan adalah sebagai berikut,

$$
\begin{aligned}
& \text { Waktu Ekstraksi : } \\
& \mathrm{A}_{1}=30 \text { menit } \\
& \mathrm{A}_{2}=40 \text { menit } \\
& \mathrm{A}_{3}=50 \text { menit } \\
& \text { Konsentrasi Ekstrak (bahan:pelarut) } \\
& \mathrm{K}_{1}=75 \% \quad(\mathrm{w} / \mathrm{v}) \\
& \mathrm{K}_{2}=50 \% \quad(\mathrm{w} / \mathrm{v}) \\
& \mathrm{K}_{3}=25 \% \quad(\mathrm{w} / \mathrm{v})
\end{aligned}
$$

Selanjutnya, data yang diperoleh dianalisis varian dan apabila ada perbedaan antar perlakuan dilanjutkan dengan uji Duncan Multiple Range Test (DMRT) pada taraf $5 \%$.

\section{e. Pengamatan}

Pengamatan yang dilakukan meliputi $\mathrm{pH}$, total fenol (Sunter, 1989), dan aktivitas antibakteri pada Escherhicia coli dan Staphylococcus aureus (Carson dan Riley, 1995).

\section{f. Analisis}

\section{Analisis $\mathrm{pH}$}

Diambil sampel sebanyak $30 \mathrm{ml}$, ditempatkan pada beaker glass. $\mathrm{pH}$ meter dikalibrasi dengan buffer $\mathrm{pH} 4$ dan 7 sebelum digunakan. Dilakukan pengukuran $\mathrm{pH}$ sampel setelah kalibrasi. $\mathrm{pH}$ meter dicelupkan pada sampel, tunggu hingga stabil, catat nilai yang tertera. 
2. Analisis Total Fenol (Sunter, 1989)

Menggunakan metode colorimetric FolinCiocalteu dengan standar asam galat, yang kemudian dianalisis hasil larutannya dengan spectrophotometer.

a) Folin Ciocalteu reagen-diencerkan dengan air suling pada rasio $1: 10$. 0,5 mL selanjutnya ekstrak rambut jagung dicampur dengan $3 \mathrm{~mL}$ diencerkan Folin Ciocalteu-reagen dan 2,5 ml $0,2 \%(\mathrm{~b} / \mathrm{v})$ larutan $\mathrm{Na}_{2} \mathrm{CO}_{3}$.

b) Campuran didiamkan selama 30 menit pada suhu kamar (sekitar $25^{\circ} \mathrm{C}$ ) dan absorbansi larutan yang dihasilkan dibaca pada $750 \mathrm{~nm}$ dengan spektrofotometer. Total fenolik ditentukan dengan kurva kalibrasi standar dan dinyatakan sebagai setara asam galat per massa kering jagung sampel sutra (ug GAE / g kering sampel).

3. Uji Aktivitas Antibakteri (Carson dan Riley, 1995)

Pada pengamatan ini metode yang digunakan adalah metode sumur difusi/sumuran, dengan pertimbangan bahwa metode ini memerlukan waktu lebih singkat dibandingkan dengan metode hitungan cawan, karena pengujian hanya secara kualitatif yaitu mengetahui ada atau tidaknya aktivitas antibakteri ekstrak rambut jagung. Prosedur metode sumur difusi adalah sebagai berikut: Kultur bakteri Escherichia coli dan Staphylococcus aureus sebanyak $1 \mathrm{ml}$ diinokulasikan ke dalam agar miring Nutrient Agar (NA) dan diinkubasi pada suhu $37^{\circ} \mathrm{C}$ selama 24 jam. Kemudian diinokulasikan ke dalam larutan Nutrient Broth (NB) secara aseptik, dikocok homogen dan diinkubasikan pada suhu $37^{\circ} \mathrm{C}$ selama 24 jam. Selanjutnya diambil larutan bakteri uji dimasukkan ke dalam media larutan agar steril yang sudah ditambah dengan Bacto Agar 0,5 \% supaya media tersebut menjadi tegar. Campuran tersebut dituangkan ke dalam cawan petri steril dan dibiarkan membeku. Setelah agar membeku, dibuat lubang (sumur) dengan diameter sekitar $6 \mathrm{~mm}$ menggunakan pipet pasteur yang ujungnya sudah dipotong sehingga panjangnya menjadi lebih kurang $5 \mathrm{~mm}$. Ekstrak rambut jagung kemudian dimasukkan ke dalam lubang sumur dan diinkubasi pada suhu $37^{\circ} \mathrm{C}$ selama 24 jam. Areal bening yang terjadi menunjukkan daerah penghambatan dan diukur mulai dari tepi sumur. Konsentrasi ekstrak rambut jagung yang dipergunakan adalah $75 \%$, $50 \%$, dan $25 \%$.

\section{HASIL DAN PEMBAHASAN}

A. Pengaruh Waktu Ekstraksi dan Konsentrasi Ekstrak Terhadap pH Ekstrak Rambut Jagung

Berdasarkan hasil sidik ragam menunjukkan bahwa lama waktu ekstraksi berpengaruh nyata terhadap $\mathrm{pH}$ ekstrak rambut jagung $(\mathrm{p}<0,05)$ sebagaimana pada Tabel 2.

Tabel 2. Rerata pH ekstrak Rambut Jagung

\begin{tabular}{cccc}
\hline \multicolumn{4}{c}{ Rerata $\mathrm{pH}$} \\
\hline Perlakuan & $\mathrm{K}_{1}$ & $\mathrm{~K}_{2}$ & $\mathrm{~K}_{3}$ \\
$\mathrm{~A}_{1}$ & $5,1^{\mathrm{c}}$ & $5,3^{\mathrm{bc}}$ & $5,2^{\mathrm{c}}$ \\
$\mathrm{A}_{2}$ & $5,4^{\mathrm{bc}}$ & $5,5^{\mathrm{b}}$ & $5,8^{\mathrm{a}}$ \\
$\mathrm{A}_{3}$ & $5,6^{\mathrm{ab}}$ & $5,7^{\mathrm{a}}$ & $5,9^{\mathrm{a}}$
\end{tabular}

1. Hasil merupakan rerata dari 3 kali ulangan

2. Rerata $\mathrm{pH}$ diikuti dengan superskrip yang berbeda menunjukkan beda nyata antar perlakuan $(\mathrm{p}<0,05)$.

Berdasarkan hasil uji lanjut DMRT, $\mathrm{pH}$ terendah dihasilkan dari perlakuan A1K1 (waktu 30 menit dengan konsentrasi kestrak $75 \%$ ) yaitu dengan rerata $\mathrm{pH} 5,1$ dan yang tertinggi pada perlakuan A3K3 (waktu 50 menit dengan konsentrasi ekstrak 25\%) dengan rerata $\mathrm{pH} 5,9$. Sedangkan pada perlakuan A2K2 (waktu 40 menit dengan konsentrasi ekstrak 50\%) rerata $\mathrm{pH}$ sebesar 5,5. Diagram batang hasil ekstraksi dengan lama waktu dan konsentrasi ekstrak rambut Jagung terhadap pH dapat dilihat pada Gambar 2.

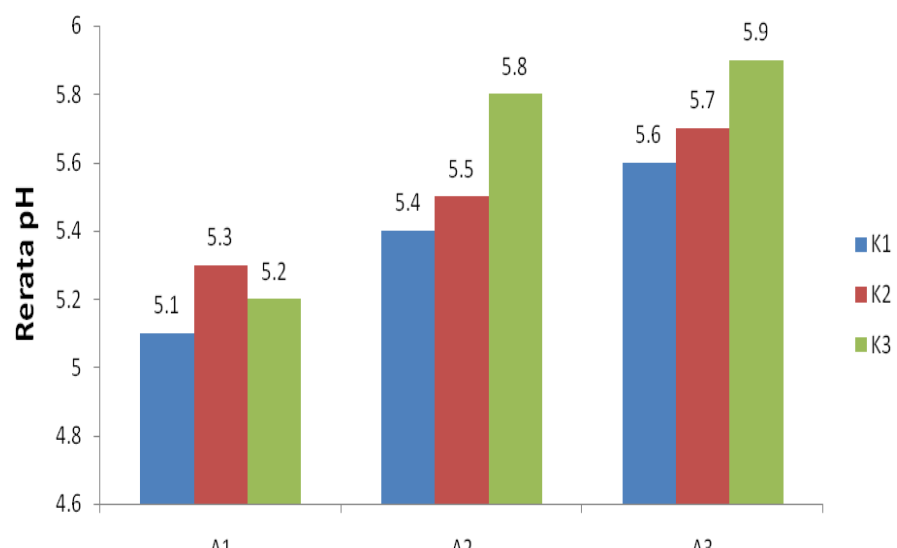

Gambar 2. Diagram batang rerata $\mathrm{pH}$ ekstrak rambut jagung

\section{B. Pengaruh Lama Waktu Ekstraksi dan Konsentrasi Ekstrak Terhadap Total Fenol Ekstrak Rambut Jagung}

Hasil sidik ragam menunjukkan beda nyata $(\mathrm{p}<0,05)$ perlakuan $\mathrm{A} 3 \mathrm{~K} 1$ (waktu 50 menit dengan konsentrasi ekstrak 75\%) menghasilkan total fenol yang lebih tinggi dibandingkan dengan perlakuan lain. Rerata total fenol dari masing-masing perlakuan dapat dilihat pada Tabel 3. 
Tabel 3. Rerata Total Fenol Ekstrak Rambut Jagung

Rerata Total Fenol ( $\mu \mathrm{gGAE} / \mathrm{g})$

$\begin{array}{cccc}\text { Perlakuan } & \mathrm{K}_{1} & \mathrm{~K}_{2} & \mathrm{~K}_{3} \\ \mathrm{~A}_{1} & 6585,88^{\mathrm{bc}} & 6512.69^{\mathrm{bc}} & 6056.04^{\mathrm{d}} \\ \mathrm{A}_{2} & 6772,56^{\mathrm{b}} & 6497,38^{\mathrm{c}} & 6309,32^{\mathrm{cd}} \\ \mathrm{A}_{3} & 7288,64^{\mathrm{a}} & 7083,33^{\mathrm{ab}} & 6990,76^{\mathrm{ab}}\end{array}$

1. Hasil merupakan rerata dari 3 kali ulangan

2. Rerata $\mathrm{pH}$ diikuti dengan superskrip yang berbeda menunjukkan beda nyata antar perlakuan $(\mathrm{p}<0,05)$

Hasil uji lanjut DMRT menunjukkan rerata total fenol tertinggi terdapat pada perlakuan A3K1 (waktu 50 menit dengan konsentrasi ekstrak 75\%) sebesar 7288,64 $\mu \mathrm{gGAE} / \mathrm{g}$ dan yang terendah sebesar 6056.04 $\mu \mathrm{gGAE} / \mathrm{g}$ pada perlakuan A1K3 (waktu 30 menit dengan konsentrasi ekstrak 25\%). Untuk lama waktu ekstraksi yang sama, semakin tinggi suhu, maka yield ekstrak, TPC (Total phenolic content), dan yield senyawa fenolik yang didapat juga semakin banyak (Margaretta et al., 2011). Hal ini diduga disebabkan karena suhu yang tinggi akan menyebabkan kelarutan senyawa phenolic dalam pelarut semakin besar. Dengan meningkatkan suhu, difusi yang terjadi juga semakin besar, sehingga proses ekstraksi juga akan berjalan lebih cepat. Akan tetapi dalam meningkatkan suhu operasi juga perlu diperhatikan, karena suhu yang terlalu tinggi dapat menyebabkan kerusakan pada bahan yang sedang diproses. Komponen bioaktif utama dalam jahe, yaitu gingerol, merupakan senyawa yang tahan panas (Miryanti, 2011).

Berikut diagram batang yang menunjukkan rerata total fenol ekstrak Ranbut Jagung dengan berbagai pelarut dalam Gambar 3 .

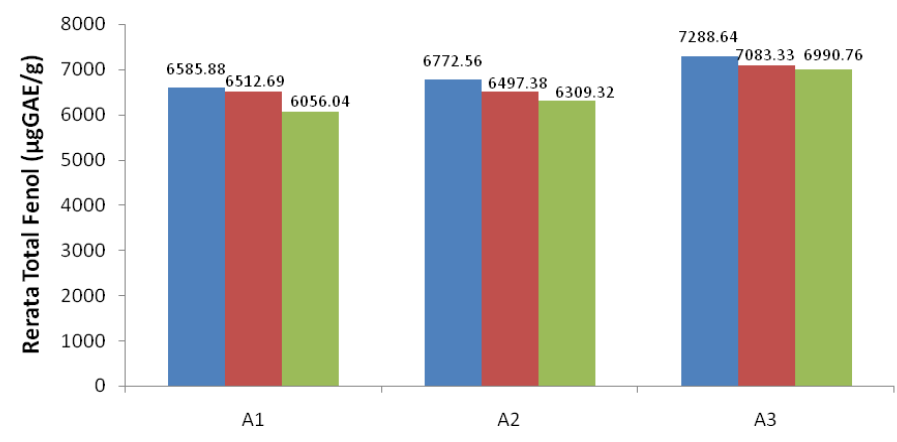

Gambar 3. Diagram batang rerata total fenol ekstrak rambut jagung

\section{Pengaruh Lama Waktu Ekstraksi dan Konsentrasi Ekstrak Rambut Jagung Terhadap Aktivitas Antibakteri pada Escherichia coli dan Staphylococcus aureus}

Hasil penelitian menunjukkan bahwa ekstrak rambut jagung dengan berbagai lama waktu ekstraksi dan konsentrasi ekstrak terhadap Escherichia coli dan
Staphylococcus aureus membentuk zona hambat bakteri. Diameter zona hambat terbesar pada masing masing bakteri uji dengan perlakuan variasi pelarut dan konsentrasi ekstrak rambut jagung dapat dilihat pada Tabel 4.

Tabel 4. Zona Hambat Bakteri Escherichia coli dan Staphylococcus aureus

\begin{tabular}{|c|c|c|c|c|}
\hline \multirow[t]{2}{*}{ Bakteri } & \multirow[t]{2}{*}{$\begin{array}{l}\text { Konsentrasi } \\
\text { (K) }\end{array}$} & \multicolumn{3}{|c|}{$\begin{array}{l}\text { Rerata Diameter Zona } \\
\text { Hambat Bakteri (mm) }\end{array}$} \\
\hline & & $\begin{array}{c}\text { Waktu } \\
30 \\
\text { menit } \\
\text { (A1) }\end{array}$ & $\begin{array}{c}\text { Waktu } \\
40 \\
\text { menit } \\
\text { (A2) }\end{array}$ & $\begin{array}{c}\text { Waktu } \\
50 \\
\text { menit } \\
\text { (A3) }\end{array}$ \\
\hline $\begin{array}{l}\text { Escherichia } \\
\text { coli }\end{array}$ & $\begin{array}{l}75 \%\left(\mathrm{~K}_{1}\right) \\
50 \%(\mathrm{~K} 2) \\
25 \%\left(\mathrm{~K}_{3}\right)\end{array}$ & $\begin{array}{c}12^{\mathrm{b}} \\
10^{\mathrm{bc}} \\
6^{\mathrm{c}}\end{array}$ & $\begin{array}{l}17^{\mathrm{ab}} \\
13^{\mathrm{b}} \\
8^{\mathrm{bc}}\end{array}$ & $\begin{array}{l}20^{\mathrm{a}} \\
16^{\mathrm{ab}} \\
11^{\mathrm{b}}\end{array}$ \\
\hline $\begin{array}{l}\text { Staphyloc } \\
\text { occus } \\
\text { aureus }\end{array}$ & 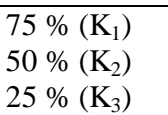 & $\begin{array}{c}15^{\mathrm{ab}} \\
10^{\mathrm{b}} \\
5^{\mathrm{d}}\end{array}$ & $\begin{array}{c}16^{\mathrm{ab}} \\
9^{\mathrm{bc}} \\
7^{\mathrm{c}}\end{array}$ & $\begin{array}{l}18^{\mathrm{a}} \\
11^{\mathrm{b}} \\
9^{\mathrm{bc}}\end{array}$ \\
\hline
\end{tabular}

1. Hasil merupakan rerata dari 3 kali ulangan

2. Rerata zona hambat diikuti dengan superskrip yang berbeda menunjukkan beda nyata antar perlakuan $(\mathrm{p}<0,05)$

Pada Tabel 4 terlihat bahwa nilai diameter zona hambat yang dihasilkan dari masing masing perlakuan berbeda. Perbedaan besarnya daya hambat pada masing masing perlakuan diduga dipengaruhi oleh lama waktu ekstraksi dan konsentrasi ekstrak yang dapat mempengaruhi keaktifan senyawa antibakteri dimana semakin tinggi konsentrasi maka zat antibakteri akan semakin tinggi juga. Menurut Masyithah (2012), kemampuan senyawa antibakteri dalam menghambat pertumbuhan bakteri dipengaruhi oleh kestabilan terhadap protein, lipid, garam dan tingkat keasaman $(\mathrm{pH})$ dalam medium pertumbuhan.

Davis stout (1971) dalam Priyatmoko (2008) menjelaskan bahwa suatu antibakteri/antibiotik dikatakan mempunyai aktivitas terhadap bakteri jika mempunyai ketentuan kekuatan sebagai berikut, luas daerah hambatan $20 \mathrm{~mm}$ atau lebih masuk kategori sangat kuat, daerah hambatan antara 10-20 mm masuk kątegori kuat, daerah hambatan antara 5-10 mm masuk kategori sedang dan daerah hambatan $5 \mathrm{~mm}$ atau kurang masuk kategori lemah.

Metode sumuran umum digunakan dalam uji aktivitas antibakteri karena lebih efektif untuk menghambat pertumbuhan bakteri dan zat aktif dapat berdifusi langsung tanpa penghalang kertas cakram (seperti pada metode Kirby Bauer). Selain itu, dengan metode ini dapat diketahui luas zona hambat. Diameter zona hambat merupakan petunjuk kepekaan bakteri uji, semakin besar zona hambat maka aktivitas antibakteri semakin besar pula (Panagan dan Syarif, 2009).

Peningkatan diameter zona hambat pada masing-masing bakteri uji diikuti dengan tingginya kandungan total fenol dan rendahnya $\mathrm{pH}$ ekstrak rambut jagung serta konsentrasi ekstrak dapat mempengaruhi kemampuan antibakteri ekstrak di 
dalam media agar sehingga mempengaruhi daya hambat, dimana semakin tinggi konsentrasi maka zat antibakteri kedalam media agar semakin tinggi. Menurut Robinson (1995), antimikroba memiliki kemampuan untuk membentuk kompleks dengan protein ekstraseluler dan protein yang dapat larut serta dengan dinding sel bakteri sehingga pertumbuhan bakteri terhambat.

Bakteri gram negatif memiliki lapisan lipopolisakarida yang menghambat senyawa antibakteri. Kemudian terjadi akumulasi yang kemudian mengganggu ikatan ikatan hidrofolik (polar) membran luar. Secara selektif sebagian dari senyawa antibakteri dengan ukuran molekul kecil masuk melalui protein porin hingga menuju sitoplasma (Djide, 2008). Diagram batang aktivitas antibakteri ekstrak rambut jagung terhadap bakteri gram negatif Escherichia coli dapat dilihat pada Gambar 4.

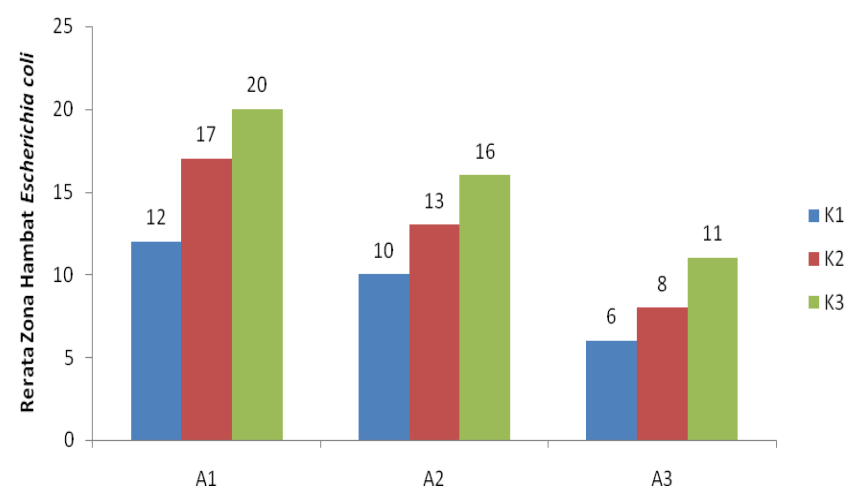

Gambar 4. Diagram batang zona hambat bakteri Escherichia coli

Menurut Djide (2008), Bakteri gram positif mengandung $40-50 \%$ peptidoglikan serta lapisan tipis asam theikoat dan asam teikuronat yang bermuatan negatif. Sedangkan pada bakteri gram negatif terdapat lapisan di luar dinding sel yang mengandung 5-20\% peptidoglikan. Pada bakteri gram positif tidak terdapat lapisan lipopolisakarida sehingga molekul senyawa antimikroba yang bersifat hidrofilik maupun hidrofobik dapat melewatinya dengan cara difusi pasif, kemudian akan berinteraksi dengan protein pada lapisan peptidoglikan sehingga menyebabkan kerusakan dinding sel. Hal ini kemudian akan menyebabkan bakteri mengalami lisis akibat tekanan osmotik yang tinggi dari dalam sel. Berikut diagram batang aktivitas antibakteri ekstrak rambut jagung terhadap bakteri gram positif Staphylococcus aureus pada Gambar 5.

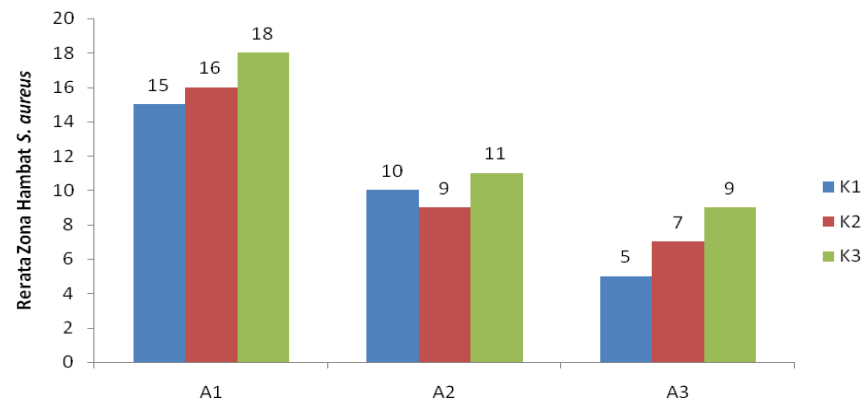

Gambar 5. Diagram batang zona hambat bakteri Staphylococcus aureus

\section{KESIMPULAN DAN SARAN}

A. Kesimpulan

Berdasarkan penelitian lama waktu dan konsentrasi ekstrak Rambut Jagung aktivitas antibakteri menghasilkan kesimpulan sebagai berikut :

1. Lama waktu terbaik untuk memperoleh ekstrak senyawa antibakteri pada ekstrak rambut jagung adalah 50 menit. Hal ini didukung oleh hasil total fenol tertinggi yang diperoleh dari perlakuan A3.

2. Ekstrak rambut jagung dengan berbagai lama waktu dan konsentrasi ekstrak terhadap Escherichia coli dan Staphylococcus aureus membentuk zona hambat bakteri. Pada perlakuan A3K1 memiliki rerata diameter zona hambat terbesar pada masingmasing bakteri uji yaitu $20 \mathrm{~mm}$ pada Escherichia coli dan $18 \mathrm{~mm}$ pada Staphylococcus aureus, sehingga ekstrak rambut jagung dengan lama waktu 50 menit dan konsentrasi ekstrak $75 \%$ memiliki aktivitas antibakteri terbaik.

3. Ekstrak rambut jagung efektif sebagai antibakteri terhadap bakteri Escherichia coli dan Staphylococcus aureus dan lebih dominan dengan mudah membunuh bakteri gram negatif dibandingkan bakteri gram positif.

\section{B. Saran}

Perlu dilakukan aplikasi pada bahan pangan dan penelitian lebih lanjut mengenai keefektifan aktivitas antibakteri rambut jagung dengan berbagai macam pelarut maupun dengan bakteri uji yang lain, serta dilakukan identifikasi lebih lanjut terhadap senyawa aktif pada ekstrak rambut jagung. 


\section{DAFTAR PUSTAKA}

Ajila CM., Leelavathi K., Prasada Rao, and UJS. 2008. Improvement of dietary fiber content and a ntioxidant properties soft dough biscuits with the incorporation of mango peel powder. J.Cereal Sci.48, 319-326.

Angkasa S. 2012. Tanpa Biji Lebat di Pot. Trubus. 512 Juli 28-29

Badan Pusat Statistik. 2015. Luas panen, produksi dan produktivitas jagung di DIY tahun 2007-2011. diakses dari http://www.bps.go.id pada tanggal 3 September 2013 .

Baye TM., Perarson TC andSettles AM. 2006. Development of calibration to predict maize seed composition using single kernel near infrared spectroscopy. Journal of Creal Science vol.43 (2), pp.236-243.

Barter P. 2007. HDL cholesterol, very low levels of LDL cholesterol and cardiovasculer event. The New England Journal of Medicine, 357, 13, $1301-1310$.

Bhaigyabati T., Ramya J., and Usha K. 2012. Effect of methanolic extract of sweet corn silk on experimentally induced hyperthyroidsm in swiss albino rats. IRJP, 3 (3).

Bhuvaneshwari K and Sivakami S. 2015. Analysis of nutrients and phytochemicals content in corn silk (Zea mays). International Journal of Science and Research (IJSR) ISSN (Online):2319-7064:79-81

BlessingtonT. 2005 The effects of cooking, storage, and ionizing irradiation on carotenoids, antioxidant activity and phenolics in potato (Solanium tuberosum L.). (Thesis). Texas A\&M University

Butsat S., Siriamornpun., and Sirithon. 2010. Antioxidant capacities and phenolic compounds of the husk, bran and endosperm of thai rice. Journal Food Chemistry, 119 (2010) : 606-613.

Dachriyanus., Katrin DO., Rika O., Olvi E., Suhatri., and Husni M. 2007. Uji efek a-mangostin terhadap kadar kolesterol total, trigliserida, kolesterol HDL dan kolesterol LDL darah mencit putih jantan serta penentuan Lethal Dosis 50 (LD50). Jurnal Sains dan Teknologi Farmasi, Vol.12, No.2, halaman 64-7.

Damayanthi E and Listyorini DI. 2006. Pemanfaatan tepung bekatul rendah lemak pada pembuatan keripik simulasi. Jurnal Gizi dan Pangan 1(2): 34-44.

Das S., Mukhopadhyay AK., and Basu D. 2009. Prospect of microwave processing an overview.Bulletin of material science.32(1):113

Dini I.,Tenore GC, and Dini A. 2013. Effect of industrial and domestic processing on antioxidant properties of pumpkin pulp. F. Sci. And Technol.53:382-385

Ebrahimzadeh MA, Pourmorad F, and Bekhradnia AR. 2008. Iron chelating activity, phenol and flavonoid content of some medicial plant from iran. African Journal of Biotechnology, 7 (18): 3188-3192.

Masduqi AF, Izzati M and Prihastanti M. 2014. Efek metode pengeringan terhadap kandungan bahan kimia dalam rumput laut Sargassum polycystum. Buletin Anatomi dan Fisologi, Volume XXII, Nomor 1, Maret 2014.

Guo J, Liu T, Han L, and Liu Y. 2009. The effect of corn silk on glycaemic metabolism. Journal Nutrition and Metabolism Biomed Central, $6: 47$.

Guo W and Beta T. 2013. Phenolic acid composition and antioxidant potential of insoluble and soluble dietary fibre extracts derived from select whole-grain cereals. Food Research
International 51: 518-525.

Hartati S, Marsono Y, Suparmo, and Santoso U. 2015. Chemical composition and antioxidant activity of rice bran hydrophilic extract of selected rice variety. AGRITECH, Vol 35, No 1, Februari 2015, pp 35-42.

Hooda S and Kawatra A. 2013. Nutritional evaluation of baby corn (Zea mays). Nutr.Food Sci.43 (pp.9-9).

Horax R., Hettiarachchy N., Kannan A., and Chen P. 2010. Proximate composition and amino acid mineral contents of Mormardica charantia L, pericarp and seeds at different maturity stages. Food Chem. 122, 1111-1115.

Hu QL, Zhang LJ, Li, YN, Ding YJ, and Li FL. 2010. Purification and antifatigue activity of flavonoids from corn silk. International Journal of Physical Sciences, 5: 321-326.

$\mathrm{Hu}$ QL and Deng Z. 2011. Protective effects of flavonoids from corn silk on oxidative stress induced by exhaustive exercise in mice. African Journal of Biotechnology, 10: 3163-3167.

Huang SH and Ng LT. 2012. Quantification of polyphenolic content and bioactive constituents of some commercial rice varieties in taiwan. Journal of Food Composition and Analysis 26: 122-127.

Iriana, I., and G.Mohamed. 2012. Biological activities and effects of food processing on flavonoids as phenolic antioxidants. http://cdn.intechopen.com/pdfs-wm/26397.pdf. Diakses tanggal 23 Januari 2016.

Iwasaki R, Murakoshi M. 1992. Palm oil yields carotene for world market. Oleochemicals, inform, Vol 3, No.2:210-217.

Lenny,S.2006. Senyawa flavonoida, fenil propanoida dan alkaloida.http://repository.usu.ac.id/bitstream/12 3456789/1842/3/06003489.pdf.txt. Diakses tanggal 23 januari 2016.

Liu J, Wang C, Wang Z, Zhang C, Lu S, and Liu J 2011. The antioxidant and free-radical scavenging activities of extract and fractions from corn silk (Zea mays L) and related flavone glycosides. Food Chemistry, 126: 261-269.

Lunven P. 1992. Maize in Human Nutrition. FAO Food and Nutrition Series 25, Rome.

Luximon-Ramma A., Bahorun T, Soobrate MA. , and Aruoma OI. 2002. Antioxidant activity of phenolic, proanthocyanidin and flavonoid components in extract of Cassia fistula. J.Agri Food Chem.50:5042-5047.

Marsono .1994. Kandungan lemak dan oryzanol bekatul dari beberapa varietas padi unggul. Laporan Penelitian Proyek Penelitian OPF/FTP-UGM. Fakultas Teknologi Pertanian. Universitas Gadjah Mada, Yogyakarta.

Mateos-Aparicio I., Mateos-Peinado C., and Ruperez P., 2010. High hydrostatic pressure improves the functionality of dietary fibre in okara byproduct from soybean. Innov. Food Sci. Emerg. Technol.11, 445-450.

Mechlouch RF., Elfalleh W., Ziadi M., Hannachi H., Chwikhi M., Aoun AB., Elakesh I, and Cheour F. 2012. Effect of drying methods on the physico-chemical properties of tomato variety rio grande. Int. J. F. Eng.8:Iss.2,Art.4. DOI: 10.1515/1556-3758.2678.

Naqvi S., Ramessar K., Farre G., Sabulza M., Miralpeix B., Twyman RM., Capell T., Zhu C., and Christou P. 2011. High-value products from transgenic maize. Biotechnol. Adv. 29, 40-53.

Nessa, Helmi A, and Muchtar, H. 2013. "Efek Diuretik dan Daya Larut Batu Ginjal dari Ekstrak Etanol Rambut Jagung (Zea mays L)" (Prosiding Seminar Nasional Perkembangan Terkini Sains Farmasi dan Klinik III). Sumatera Utara: 
Fakultas Farmasi Universitas Andalas.

Nurhanan AR, Rosli WIW, and Mohsin SSJ. 2012. Total polyphenol content and free radical scavenging activity of corn silk (Zea mays hairs). Sain Malysiana, 40 (2):155-161.

Nurhanan AR. and Rosli WIW. 2014. Nutritional compositions and antioxidative capacity of the silk obtained from immature and mature corn. Journal of King Saud University-Science (2014) 26, 119-127.

Odhav B., Beekrum S., Akula U., and Baijnath H. 2007. Preliminary assessment of nutritional value of traditional leafy vegetables in Kwa Zulu-Natal, South Africa. J.Food Compos. Anal. 20, 430-435.

Qiao, L.Y.Sun, R.Chen, Y.Fu, W.Zhang, X., Li, J.Chen, Y.Shen, X, Ye. 2014. Sonochemical Effects on 14 flavonoids commom in citrus. Relation to stability. Plos ONE 9 (2):e87766.

Rahmayani A. 2007. Telaah Kandungan Kimia Rambut Jagung (Zea mays L). Institut Pertanian Bogor: Bogor.

Ramadani FH, Intannia D, and Ni'mah M. 2016. Profil penurunan kadar glukosa darah ekstrak air rambut jagung (Zea mays L) tua dan muda pada mencit dan jantan galur balb-c. Jurnal Pharmascience 3(1): 37-44

Ramessar K., Sabalza M., Capell T., and Christou P. 2008. Maize plants: an ideal production platform for effective and safe molecular pharming. Plant Sci.174, 409-419.

Reblova, Z. 2012. Effect of Temperature on the Antioxidant Activity of Phenolic Acids. Czech Journal of Food Science Vol 30 No 2: 171-177.

Ren SC, Liu ZL, and Ding XL. 2009. Isolation and identification of two novel flavone glycosides from corn silk (Stigma maydis). J Med Plants Res, 3(12): 1009-1015.

Riani N., Amir A, Alkil M., and Momuat EO .2001. Pengaruh berbagai takaran nitrogen terhadap pertumbuhan dan hasil tanaman jagung hibrida dan bersari bebas. Risalah Penelitian Jagung dan Serelia Lain, Vol. $5: 21-25$

Rosli W.I.W., and Anis JC. 2012. The potential of Zea mays ears and it extracts as an alternative ingridients. APCBEE PAROCEDIA 2, 141-147.

Sachin V., Jangram, CL, Low, and Mujumdar AS. 2010. Drying of food, vegetables, and fruit. Volume 1. ISBN: 978-0806759-1

Sarfare S., Menon S., and Shailajan. 2010 Corn silk as bioavainable source of betasitosterol : A Pharmacokinetic study using HPTLC. Asian Journals of Plant Scine. 1-7

Sarepoua E, Tangwangchai, Suriharn B, and Lertrat J. 2013. Relationships between phytochemicals and antioxidant activity in corn silk. International Food Research Journal, 20 (5): 2073-2079.

Sarepoua E, Tangwangchai, Suriharn B, and Lertrat J. 2015. Influence of variety and harvest maturity on phytochemical content in corn silk. Food Chemistry Journal, 169 (2015) : 424-429.

Sari DK., Eardhani DH., and Prasetyaningrum A. 2012. Pengujian kandungan total fenol Kappahycus alvarezzi dengan metode ekstraksi ultrasonic dengan variasi suhu dan waktu. Jurusan teknik kimia fakultas teknik UNDIP. Prosiding SNST ke-3 tahun 2012. Fakultas Teknik Universitas Wahid Hasyim, Semarang.

Seebauer JR., Moose SP., Fabbri BJ., Crossland LD. , and Below FE. 2004. Amino acid metabolism in maize earshoots. Implications for assimilate preconditioning and nitrogen signaling. Plant Physiol. 136, 4326.4334.

Sholihah MA, Nurhanan AR, and Rosli WIW 2012. Phytochemicals screening and total phenolic content of malaysian Zea mays hair extracts. International Food Research Journal,19 (4): $1533-1538$.

Sompong R., Siebenhandl-Ehn S., Linsberger-Martin G., and Berghofer E. 2011. Physicochemical and antioxidative properties of red and black rice varieties from Thailand, China and Sri Lanka. Food Chemistry 124:132-140.

Sukmawati NMH. 2008. Pengaruh ekstrak rambut jagung (Maydis stigma) terhadap histologi ginjal dan ekspresi gen pada tikus yang diinduksi gentamisin dan piroksikam. Bandung: ITB.

Tuminah, S. 2004. Teh (Camellia sinensis) sebagai salah satu sumber antioksidan. Cermin Dunia Kedokteran. No.144:52-54.

Utariningsih D. 2007. Dekok rambut jagung (Zea mays) efektif dalam menurunkan kadar kolesterol tikus putih (Rattus norvegicus). Malang: Universitas Muhammadiyah Malang.

Vatai T., Skerget M., and Knez Z. 2009. Extraction of phenolic compounds from elder berry and different grape marc varieties using organic solvents and/or supercritical carbodioxide. J.Food Eng.

Vova N., Varga B., Kricka T., Curic D., Jurisic V., and Matin A. 2009. Progress in ethanol production from corn kernel by applying cooking pretreatment. Bioresour. Technol. 100, 2712-2718.

Wang C, Zhang T, Liu J, Lu S, Zhang C,Wang E, Wang Z, Zhang Y, and Liu J. 2011. Subchronic toxicity study of corn silk with rats. Journal of Ethnopharmacology, 137: 36-43.

Winarno, FG. 2002. Kimia Pangan dan Gizi, Gramedia, Jakarta.

Yondra, AD, Jose C, and H.Y.2014. Teruna, total fenolik, flavonoid serta aktivitas antioksidan ekstrak n-heksana, diklorometan dan metanol amaranthus spinosus 1 em5-bawang merah. JOM FMIPA 1 (2):359-369.

Yosmar R, Arifin H, dan Mustika R. 2014. Pengaruh ektrak etanol rambut jagung (Zea mays L) terhadap kadar kolesterol. 